\title{
EVALUASI KEPATUHAN PASIEN ANAK PENDERITA DIARE TERHADAP PENGGUNAAN ANTIBIOTIK DI RUMAH SAKIT UMUM (RSU) KARYA BAKTI UJUNG BANDAR RANTAUPRAPAT
}

\author{
Roby Gultom, Khairani \\ Universitas Imelda Medan
}

\begin{tabular}{l}
\hline \hline Article Info \\
\hline Article history: \\
Received Mar 03, 2021 \\
Revised Mar 22, 2021 \\
Accepted Mar 25, 2021
\end{tabular}

Keywords:

Diarrhea

Antibiotics

Rational

\begin{abstract}
Diarrhea is one of the leading causes of death in children in the world. Most diarrhea is caused by viruses, bacteria and parasites. Treatment of diarrhea in children requires treatment using antibiotics. The administration of antibiotics if it is not appropriate can increase the cost of the drug and have side effects related to the problem of immunity to certain microbes. The purpose of this study was to evaluate the Karya Bakti Ujung Bandar Rantauprapat General Hospital (RSU) in 2019. The purpose of this study was to determine the compliance of children with diarrhea with antibiotic use and how to use drugs in patients with diarrhea in children based on the patient's right, the right indication, the right medicine and the right dose in the inpatient room at RSU Karya Bakti Ujung Bandar Rantauprapat. The number of samples in this study was conducted on 42 children consisting of 20 male patients and 22 female patients. This study used statistical methods. Data collection was carried out retrospectively from the installation of medical records for diarrhea patients in children in the inpatient room of Karya Bakti Hospital. Ujung Bandar Rantauprapat in 2019. The results of research on the distribution of rationality based on the right patient, the right indication, the right drug and the right dose show that all of them have accuracy with a percentage of 100 .
\end{abstract}

This is an open access article under the CC BY-SAlicense.

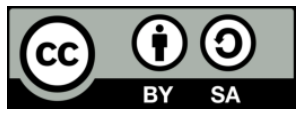

\section{Corresponding Author:}

Roby Gultom,

Program Studi S1 Farmasi,

Universitas Imelda Medan,

Jl. Bilal No. 52 Kelurahan Pulo Brayan Darat I Kecamatan Medan Timur, Medan - Sumatera Utara.

Email: roby.gultom@gmail.com

\section{INTRODUCTION}

Diare merupakan salah satu penyakit infeksi yang dapat mengakibatkan kematian pada bayi dan anak (Kemenkes RI, 2015). Diare adalah buang air besar sebanyak tiga kali atau lebih dalam satu hari dengan konsistensi cair. Diare menghasilkan feses berwujud cair dibandingkan feses normal pada umumnya dan frukuensi buang air besar menjadi lebih sering. Umumnya setiap anak dapat melakukan Buang Air Besar (BAB) tidak mencapai tiga kali sehari, namun jika frukuensi $\mathrm{BAB}$ lebih dari tiga kali sering terjadi maka dapat disebut sebagai diare meskipun tidak selalu (Arifianto, 2012). 
Data WHO menjelaskan bahwa diare merupakan keadaan dimana meningkatnya frekuensi buang air besar lebih dari tiga kali dalam sehari dengan disertai adanya perubahan konsisten feses (lebih cair) dengan atau tanpa darah. Secara klinis diare dapat digolongkan sebagai berikut diarea cair akut, disentri, serta diare persisten. Data (WHO, 2015) angka kematian akibat diare pada balita di negeri india sebanyak $42 \%$ dan angka kesakitan balita dengan diare senyak 39\%. Menurut WHO penyakit diare merupakan penyakit pertama penyebab kematian kedua pada anak dibawah 5 tahun, dan bertanggung jawab memberikan kematian pada anak sebanyak 525.000 setiap tahun. Diare sebagai penyebab utama kematian anak dan sebagai penyumbang morbiditas di dunia, dan sisanya berasal dari makanan dan sumber air yang terkontaminasi (kotor). Diseluruh dunia terdata 780 juta manusia belum mendapatkan akses air bersih yang lebih baik dan 2,5 milyar belum memiliki sanitasi yang layak pakai (WHO, 2017).

Di Indonesia kematian anak dan balita masih sangat tinggi yang disebabkan oleh diare dengan prevalensi tertinggi terdeteksi pada anak berusia 1-4 tahun dengan persentase 16,7\% pada tahun 2003 hingga 2010, berdasarkan survey morbiditas yang dilakukan oleh Subdit diare, insiden diare cendrung naik yakni tahun 2003 sebanyak $374 / 1000$ penduduk, tahun2006 naik menjadi 432/1000 pendudukdan tahun 2010 menjadi 411 /1000 penduduk (Kemenkes RI, 2011). Berdasar profil data Kesehatan Indonesia tahun 2016, menunjukkan kasus diare di provinsi Sulawesi Utara berjumlah 6.337 orang $(9,7 \%)$ dan perkiraan diare difasilitas kesehatan berjumlah 65.127 orang (Kemenkes RI, 2017).

Diare dapat disebabkan kerena adanya faktor infeksi virus, bakteri dan parasite. Selain itu faktorfaktor yang dapat mempengaruhi timbulnya penyakit diare antara lain: faktor makanan, keadaan gizi, keadaan sosial ekonomi dan keadaan lingkungan sekitarnya. Diare akan berbahaya jika mengakibatkan dehidrasi, kekurangan cairan dan elektrolit akan mengakibatkan kematian. Penatalaksanaan diare akut anak. (World Gastroenterology Organization, 2012) terdiri dari terapi rehidrasi oral, terapi suplemen zink, diet, probiotik, dan antibiotik.

Antibiotik merupakan obat yang umum digunakan untuk melawan infeksi yang disebabkan oleh bakteri. Sekitar 40-62\% studi menunjukkan bahwa penggunaan antibiotik tidak hanya untuk penyakit sebenarnya yang tidak memerlukan antibiotik. Kualitas penggunaan antibiotik diberbagai pelayanan kesehatan dilaporkan 30-80\% belum didasarkan pada hasil indikasi. Efektivitas penggunaan antibiotik yang tinggi dapat memberikan resistensi bakteri terhadap antibiotik itu sendiri, yang berpengaruh pada morbiditas dan mortalitas (Kemenkes, 2011). Penggunaan obat antibiotik yang tidak sesuai (tidak rasional) dengan podoman terapi, akan meningkakan berkembangnya resistensis bakteri terhadap antibiotik. Namun, hadirnya resistensi dapat dicegah dengan cara mengkomsumsi antibiotik dengan rasional dan teratur, sehingga resistensi tidak terjadi yang dapat menghambat tingginya biaya pengobatan, serta meningkatkan pelayanan kesehatan (Kemenkes, 2011).

Pengobatan infeksi yang diakibatkan oleh bakteri salmonella ini adalah pengobatan dengan menggunakan antibiotik. Antibiotik adalah obat yang sering digunakan pada kasus infeksi yang diakibatkan oleh bakteri. kepatuhan antibiotik yang tepat dibutuhkan untuk mengatasi masalah resistensi antibiotik. Resistensi antibiotik adalah perubahan bakteri sehingga menjadi kebal terhadap antibiotik (WHO, 2011).

Masalah yang nantinya akan diterima oleh pasien jika menggunakan antibiotik yang kurang tepat (resistensi) akan mengakibatkan pengobatan yang kurang efektif, dapat mengakibatkan tejadinya resiko keamanan bagi pasien, resistensi terhadap antibiotik dan menyebabkan pemborosan biaya yang tidak dapat mencapai tujuan terapi (Kemenkes, 2011).

Berdasarkan latar belakang tersebut, peneliti ingin mengetahui dan mengevaluasi kepatuhan pasien anak penderita diare terhadap pemberian obat antibiotik dengan menggunakan deskriptif tepat indikasi, tepat pasien, tepat dosis dan tepat obat di Rumah Sakit Umum (RSU) Karya Bakti Ujung Bandar Rantauprapat. Adapun tujuan pada penelitian ini untuk mengetahui kepatuhan pasien anak penderita diare terhadap penggunaan antibiotik serta bagaimana penggunaan obat pada pasien diare pada anak berdasarkan tepat pasien, tepat indikasi, tepat obat dan tepat dosis di ruang rawat inap RSU Karya Bakti Ujung Bandar Rantauprapat.

\section{RESEARCH METHOD}

Sampel adalah bagian dari sejumlah cuplikan penelitian yang dipilih dari populasi dan diteliti secara akurat (Mahir, 2016). Sampel pada penelitian ini adalah pasien diare anak yang tercantum dalam rekam medik menggunakan terapi antibiotik di Ruang Inap RSU Karya Bakti Ujung Bandar Rantauprapat tahun 2019, sampel yang diambil pada penelitia ini sebanyak 42 sampel.

Penelitian ini dilakukan di RSU Karya Bakti Ujung Bandar Rantauprapat bulan Juli-Agustus 2020 pengambilan data yang teliti sudah terjadi ditahun 2019 direkam medik di RSU Karya Bakti Ujung Bandar Rantauprapat. 
Alat

Alat yang digunakan adalah formulir pengambilan data yang dirancang sesuai dengan kebutuhan penelitian, seperti alat tulis untuk mencatat data.

Bahan

Bahan yang digunakan adalah data rekam medik pasien yang dicatat pada lembar pengumpulan data meliputi: nomor rekam medik, identitas pasien (jenis kelamin dan usia), diagnosis, antibiotik untuk pasien diare pada anak yang diberikan, tanggal masuk, tanggal ke luar rumah sakit, dan lama rawat inap.

Data yang diperoleh dianalisis dengan metode deskriptif yaitu non eksperimental dan kemudian diolah, untuk mengetahui rasonalitas penggunaan antibiotik pada pasien diare pada anak di RSU Karya Bakti Ujung Bandar Rantauprapat tahun 2019 dan hasil dievaluasi rasionalitasnya berdasarkan standar pengobatan sehingga persentase rasionalitas penggunaan antibiotik di RSU Karya Bakti Ujung Bandar Rantauprapat tahun 2019.

\section{RESULTS AND ANALYSIS}

Distribusi Pasien Berdasarkan Dengan Jenis Kelamin

Pengelompokan distribusi pasien berdasarkan jenis kelamin bertujuan untuk mengetahui jenis kelamin mana yang banyak terjadi kasus diare pada anak, seperti yang terlihat pada tabel berikut.

Tabel 1. Karakteristik Pasien Anak di RSU Karya Bakti Ujung Bandar Rantauprapat Tahun 2019 Berdasarkan Jenis Kelamin

\begin{tabular}{cccc}
\hline No & Karakteristik & Frekuensi & Persentase \% \\
\hline 1 & Laki-Laki & 20 & 48 \\
\hline 2 & Perempuan & 22 & 52 \\
\hline & Jumlah & $\mathbf{4 2}$ & $\mathbf{1 0 0}$
\end{tabular}

Berdasarkan tabel 1 di atas dapat dilihat bahwa penderita diare pada anak yang dirawat di Rumah Sakit Umum Karya Bakri Ujung Bandar Rantauprapat pada tahun 2019 lebih banyak pada pasien perempuan yaitu 22 pasien (50\%) dan 20 pasien laki-laki (48\%). Dari tabel diatas dapat dilihat bahwa terdapat perbedaan angka yang tidak begitu jauh mengenai kejadian diare pada anak perempuan dan laki-laki. Penelitian ini dapat menunjukkan bahwa anak perempuan lebih banyak menderita diare dibandingkan dengan anak lakilaki dikarenakan anak perempuan mempunyai daya tahan tubuh yang lebih rendah dibandingkan dengan daya tahan tubuh anak laki laki.

\section{Distribusi Pasien Berdasarkan Umur}

Tabel 2. Distribusi Pasien Diare Pada Anak di RSU Karya Bakti Ujung Bandar Rantauprapat Tahun 2019 Berdasarkan Umur

\begin{tabular}{cccc}
\hline No & Umur & Frekuensi & Persentase \% \\
\hline 1 & 1 tahun & 7 & 16,7 \\
\hline 2 & 2 tahun & 3 & 7,1 \\
\hline 3 & 3 tahun & 4 & 9,5 \\
\hline 4 & 4 tahun & 4 & 9,5 \\
\hline 5 & 5 tahun & 5 & 11,9 \\
\hline 6 & 6 tahun & 5 & 11,9 \\
\hline 7 & 7 tahun & 4 & 9,5 \\
\hline 8 & 8 tahun & 4 & 9,5 \\
\hline 9 & 9 tahun & 3 & 7,1 \\
\hline 10 & 10 tahun & 2 & 4,8 \\
\hline 11 & 11 tahun & 1 & 2,4 \\
\hline & Jumlah & $\mathbf{4 2}$ & $\mathbf{1 0 0}$ \\
\hline
\end{tabular}

Berdasarkan tabel 2 diatas terlihat gambaran tentang pengobatan pasien diare pada anak yang dapat diklasifikasikan berdasarkan umur 1 tahun adalah umur yang paling banyak terkena diare yaitu 7 pasien (17\%) umur 5-6 tahun adalah umur kedua yang di serang diare yaitu 5 pasien (12\%), dan yang ketiga umur 3,4,7,8 tahun yaitu 4 pasien (10\%), umur 2 atau 9 tahun yaitu 3 pasien (7\%) sedangkan umur 11 tahun yaitu 1 pasien $(2 \%)$. Anak-anak adalah kelompok umur yang paling banyak terserang penyakit diare. Penelitian ini membuktikan bahwa penyakit diare banyak menyerang anak-anak karena pertahanan tubuh pada anak-anak masih lemah. 


\section{Distribusi Pasien Berdasarkan Lama Inap (LOS)}

Pengelompokan distribusi pasien berdasarkan lama rawat inap bertujuan untuk mengetahui berapa lama rata-rata rawat inap tiap pasien di rawat inap Rumah Sakit Karya Bakti Ujung Bandar Rantauprapat Tahun 2019, seperti yang terlihat pada tabel berikut:

Tabel 3. Distribusi Pasien Diare Pada Anak Di RSU Karya Bakti Ujung Bandar Rantauprapat Tahun 2019 Berdasarkan Lama Inap (LOS)

\begin{tabular}{cccc}
\hline No & Lama inap (LOS) & Frekuensi & Persentase \% \\
\hline 1 & 3 hari & 25 & 59,5 \\
\hline 2 & 4 hari & 14 & 33,3 \\
\hline 3 & 5 hari & 2 & 4,8 \\
\hline 4 & 6 hari & 1 & 2,4 \\
\hline & Jumlah & $\mathbf{4 2}$ & $\mathbf{1 0 0}$ \\
\hline
\end{tabular}

Berdasar tabel 3 diatas menunjukkan lama rawat inap pasien diare pada anak di rawat inap Rumah Sakit Karya Bakti Ujung Bandar Rantauprapat Tahun 2019. Semua data rekam medik tersebut memenuhi kriteria inklusi. Prevalensi rawat inap tertinggi adalah 3 hari sebanyak 25 pasien dengan persen $(60 \%)$ dan yang tertinggi kedua yaitu 4 hari sebanyak 13 pasien dengan persen $(33 \%)$ dan yang tertinggi ketiga yaitu 5 hari sebanyak 2 pasien (5\%), dan rawatan 6 hari yaitu 1 pasien $(2 \%)$. Pasien yang diperbolehkan pulang karena kondisi pasien sudah sembuh atau melakukan rawat jalan dan dapat meneruskan terapi lanjutan dirumah karena sudah merasa lebih baik atau sembuh.

\section{Distribusi Pasien Diare Pada Anak Berdasarkan Antibiotik Yang Digunakan}

Pengelompokan distribusi pasien berdasarkan antibiotik yang digunakan bertujuan untuk mengetahui jenis antibiotik yang paling banyak dan digunakan oleh pasien diare pada anak di di ruang rawat inap Rumah Sakit Umum Karya Bakti Ujung Bandar Rantauprapat Tahun 2019 dapat dilihat pada tabel berikut:

Tabel 4. Distribusi Pasien Diare Pada Anak di RSU Karya Bakti Ujung Bandar Rantauprapat Tahun 2019 Berdasarkan Penggunaan Antibiotik

\begin{tabular}{clcc}
\hline No & Nama antibiotik & Frekuensi & Persentase $\%$ \\
\hline 1 & Metronidazole & 9 & 21,4 \\
\hline 2 & Ceftriaxone, metronidazole & 6 & 14,3 \\
\hline 3 & Cotrimoxazole, metronidazole & 5 & 11,9 \\
\hline 4 & Ceftriaxone, cefixime & 13 & 31,0 \\
\hline 5 & Cefixime & 2 & 4,8 \\
\hline 6 & Cotrimoxazole, cefixime & 3 & 7,1 \\
\hline 7 & Ceftriaxone & 4 & 9,5 \\
\hline & Jumlah & $\mathbf{4 2}$ & $\mathbf{1 0 0}$ \\
\hline
\end{tabular}

Berdasarkan tabel 4 diatas data yang diperoleh terdapat 7 jenis antibiotik yang paling banyak diresepkan pada pasien diare pada anak di ruang rawat inap Rumah Sakit Umum Karya Bakti Ujung Bandar Rantauprapat Tahun 2019. Ceftriaxone $=25$, Metronidazole $=22$ cefixime $=16$, dan Cotrimaxazole $=7$ merupakan antibiotik yang umum digunakan dibandingkan dengan antibiotik yang lain. Antibiotik yang banyak digunakan dari golongan sefalosforin (ceftriaxone dan Metronidazole). (ceftriaxone dan metronidazole) adalah golongan antibiotik yang umum digunakan di ruang rawat inap Rumah Sakit Karya Umum Bakti Ujung Bandar Rantauprapat Tahun 2019.

\section{Evaluasi Ketepatan Penggunaan Antibiotik}

Evaluasi penggunaan antibiotik dilakukan terhadap 42 data rekam medik pasien diare pada anak di ruang rawat inap Rumah Sakit Umum Karya Bakti Ujung Bandar Rantauprapat Tahun 2019. Penggunaan antibiotik yang tidak tepat dapat mengakibatkan pengobatan menjadi kurang efektif dan terjadinya resistensi. Penggunaan obat yang rasional yaitu jika memenuhi kriteria tepat indikasi, tepat obat, tepat pasien dan tepat dosis.

\section{Tepat Indikasi}

Setiap obat memberikan efek terapi yang spesifik. Contohnya antibiotik digunakan untuk infeksi bakteri, sehingga pemberian antibiotik hanya ditujukan untuk pasien akibat infeksi bakteri. Pengobatan dikatakan sudah tepat indikasi apabila antibiotik yang diberikan berdasarkan diagnosis diare. Tepat indikasi pada penelitian ini adalah penggunaan antibotik berdasarkan adanya inikasi pada diare. 
Tabel 5. Evaluasi Ketepatan Indikasi Penggunaan Antibiotik Pada Pasien Diare Dirawat Inap RSU Karya Bakti Ujung Bandar Rantauprapat Tahun 2019

\begin{tabular}{cccc}
\hline No & Hasil & Jumlah resep & Persentase $\%$ \\
\hline 1 & Tepat indikasi & 70 & 100 \\
\hline 2 & Tidak tepat indikasi & 0 & 0 \\
\hline & Jumlah & $\mathbf{7 0}$ & $\mathbf{1 0 0}$
\end{tabular}

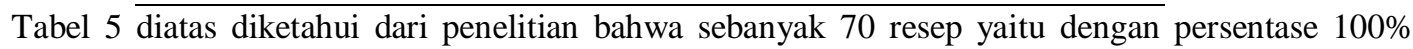
sudah tepat indikasi. Antibiotik yang digunakan adalah ceftriaxone, cefixime, metronidazole, cotrimoxazole adalah golongan sefalosforin yang menurut literatur antibiotik ini dapat digunakan untuk terapi pengobatan pada diare, dengan demikian semua antibiotik yang digunakan pada pasien diare di ruang rawat inap Rumah Sakit Umum Karya Bakti Ujung Bandar Rantauprapat Tahun 2019 yaitu 100\% tepat indikasi.

\section{Tepat Dosis}

Dosis, cara dan lama pemberian obat sangat berpengaruh terhadap efek terapi obat. Pemberian dosis yang tidak wajar, terkhusus obat yang memiliki interaksi terapi yang sempit, sangat beresiko menghasilkan efek samping. Sebaliknya dosis yang kecil belum menjamin memberikan hasil terapi yang diharapkan.

Tabel 6. Evaluasi Ketepatan Dosis Penggunaan Antibiotik pada Pasien diare pada Anak di Rawat Inap Rumah Sakit Umum Karya Bakti Ujung Bandar Rantauprapat Tahun 2019

\begin{tabular}{cccc}
\hline No & Hasil & Jumlah Resep & Persentase \% \\
\hline 1 & Tepat dosis & 70 & 100 \\
\hline 2 & Tidak tepat dosis & 0 & 0 \\
\hline Jumlah & $\mathbf{7 0}$ & $\mathbf{1 0 0}$ \\
\hline
\end{tabular}

Tabel 6 diatas menjelaskan bahwa penggunaan antibiotik di ruang rawat inap Rumah Sakit Umum Karya Bakti Ujung Bandar Rantauprapat Tahun 2019, diketahui sebanyak 70 resep yaitu 100\% dinyatakan tepat dosis.

\section{Tepat Obat}

Tepat obat adalah pemilihan obat yang harus mempunyai efek terapi yang sesuai dngan penyakitnya dengan mempertimbangkan keefektifan, keamanan, kecocokan obat bagi pasien serta ada dalam daftar obat yang telah direkomendasikan.

Tabel 7. Evaluasi Ketepatan Obat Penggunaan Antibiotik Pada Pasien Diare Pada Anak di rawat Inap RSU Karya Bakti Ujung Bandar Rantauprapat Tahun 2019

\begin{tabular}{cccc}
\hline No & Hasil & Jumlah Resep & Persentase \% \\
\hline 1 & Tepat obat & 70 & 100 \\
\hline 2 & Tidak tepat obat & 0 & 0 \\
\hline & Jumlah & $\mathbf{7 0}$ & $\mathbf{1 0 0}$ \\
\hline
\end{tabular}

Tabel 7 diatas diketahui sebanyak 70 resep yaitu 100\% dari total keseluruhan resep dikatakan tepat obat, sedangkan resep yang dikatakan tidak tepat obat dinyatakan $100 \%$. Hal ini dikatakan pasien diare pada anak yang dirawat di Rumah Sakit Karya Bakti Ujung Bandar Rantauprapat Tahun 2019 dikatakan tepat obat.

\section{Tepat pasien}

Ketepatan pasien mencakup pertimbangan antara lain apakah ada kontraindikasi atau adalah kondisi-kondisi khusus yang memerlukan penyesuaian dosis secara individual.

Tabel 8. Evaluasi Ketepatan Pasien Penggunaan Antibiotik Pada Pasien Diare Pada Anak di rawat Inap RSU Karya Bakti Ujung Bandar Rantauprapat Tahun 2019

\begin{tabular}{cccc}
\hline No & Hasil & Jumlah Pasien & Persentase \% \\
\hline 1 & Tepat pasien & 42 & 100 \\
\hline 2 & Tidak tepat pasien & 0 & 0 \\
\hline & Jumlah & $\mathbf{4 2}$ & $\mathbf{1 0 0}$ \\
\hline
\end{tabular}

Tabel 8 diatas menunjukkan bahwa dari 42 pasien yaitu sebanyak 100\% pasien diare pada anak di ruang rawat inap Rumah Sakit Karya Bakti Ujung Bandar Rantauprapat Tahun 2019 dikatakan tepat pasien berdasarkan dengan diagnosis dokter. Antibiotik yang diberikan yaitu ceftriaxone, cefixime metronidazole dan cotrimoxazole tidak menimbulkan hipersensitivitas terhadap pasien yang menggunakan.

Dari penelitian ada kesesuaian yang dapat dilihat untuk penggunaan antibiotik pada pasien diare pada anak di ruang rawat inap Rumah Sakit Karya Umum Bakti Ujung Bandar dengan penatalaksanaan diare 
pada anak yaitu tepat indikasi, tepat pasien, tepat dosis dan tepat indikasi. Hasil dari evaluasi penggunaan antibiotik di ruang rawat inap Rumah Sakit Karya Bakti Ujung Bandar Rantauprapat Tahun 2019 yang rasional berdasarkan kriteria.

\section{CONCLUSION}

1. Evaluasi kepatuhan pasien anak penderita diare terhadap penggunaan antibiotik pada pengobatan di ruang rawat inap Rumah Sakit Umum Karya Bakti Ujung Bandar Rantauprapat Tahun 2019 sudah rasional yang meliputi.

2. Penggunaan antibiotik pada pengobatan diare anak di ruang rawat inap Rumah Sakit Karya Umum Bakti Ujung Bandar Rantauprapat Tahun 2019 sudah sesuai dengan standar keputusan Kementerian Kesehatan.

3. Berdasarkan kriteria umur yang terkena penderita diare pada anak-anak diperoleh hasil bahwa perempuan lebih banyak terkena diare dibandingkan laki-laki di Rumah Sakit Umum Karya Bakti Ujung Bandar Rantauprapat pada tahun 2019.

Adapun saran peneliti adalah sebagai berikut:

1. Pentingnya pemilihan pengobatan antibiotik yang sesuai dengan anak.

2. Perlunya kerjasama yang baik antara dokter dan apoteker guna mencegah terjadinya pengobatan yang tidak rasional melalui beberapa usaha diantaranya dengan melakukan MESO (Monitoring Efek Samping).

3. Pentingnya komunikasi dan kerjasama antara tenaga medis sehingga tercapai pengobatan yang tepat.

\section{REFERENCES}

Anonim. 2014. Penggunaan Antibiotik Secara Bijak Dalam Peningkatan Penggunaan Obat Rasional. Jakarta Departemen Kesehatan RI.

Ariani, A. Putri. 2016. Diare pencegahan dan pengobatanya. Yogyakarta: Nuha Medika.

Kemenkes RI. 2011. Situasi Diare di Indonesia. Jakarta: Kementerian Kesehatan Republik Indonesia.

Kementrian Kesehatan RI. 2011. Pedoman pelayanan kefarmasian untuk terapi antibiotik. Jakarta: Kementrian Kesehatan RI

Kementrian Kesehatan RI. 2011. Pedoman Penggunaan Antibiotik. Jakarta: Kementrian Kesehatan RI.

Kementrian Kesehatan RI. 2015. Program Pengendalian Resistensi Antimikroba di Rumah Sakit. Jakarta: Kementrian Kesehatan RI.

Kementrian Kesehatan RI. 2019. Klasifikasi dan Perizinan Rumah Sakit. Jakarta: Kementrian Kesehatan RI.

Kementrian Kesehatan Republik Indonesia. 2015. Profil Kesehatan Indonesia. Jakarta: Kementrian Kesehatan Republik Indonesia. Diakses tanggal 10 Juli 2020.

Peraturan Mentri Kesehatan Republik Indonesia. 2011. Podoman Umum Penggunaan Antibiotik. Jakarta: Kementrian Kesehatan RI. Diakses 10 Juli 2020.

Permenkes RI. 2011. Podoman umum penggunaan antibiotik. Peraturan Mentri Kesehatan Republik Indonesia nomor 2406/Mankes/Per/Xll/2011.

Soebagyo, B. 2013. Diare Akut pada Anak. Surakarta: Sebelas Maret University Press.

World Health Organization (WHO). 2009. Pelayanan Kesehatan anak di rumah sakit. Tim Adaptasi Indonesia. Diare Akut. Jakarta: WHO Indonesia. 